\title{
Chilaiditi syndrome mimicking congestive heart failure
}

\author{
Julie Omolola Okiro
}

Department of Medicine, Sligo University Hospital, Sligo, Ireland

\section{Correspondence to}

Dr Julie Omolola Okiro, Julieokiro@gmail.com

Accepted 12 June 2017

\section{DESCRIPTION}

An 85-year-old man presented with orthopnoea and dyspnoea, symptoms of which were suspicious for heart failure. He was in respiratory distress and oxygen saturation was $85 \%$ on $4 \mathrm{~L}$ oxygen. On initial assessment, lungs were clear and heart sounds were normal. What was immediately evident was a distended abdomen. Digital rectal examination revealed hard faeces in rectum. He had a history of chronic constipation and last bowel movement was over 5 days ago.

Chest X-ray (figure 1) showed raised diaphragms with loops of large bowel interposed between the right hemidiaphragm and liver. An abdominal X-ray (figure 2) confirmed faecal impaction. Brain natriuretic peptide, d-dimer and echocardiogram were normal. He eventually underwent manual evacuation following failure of oral laxatives and enemas (figure 3 for follow-up chest X-ray).

This chest X-ray shows Chilaiditi sign (CS), a rare anomaly where bowel lies between the liver and right diaphragm. CS may be congenital or acquired. Chronic constipation is a recognised cause of acquired CS. Other acquired causes are cirrhosis, raised intra-abdominal pressure and diaphragmatic paralysis. ${ }^{1}$ CS is asymptomatic but when causing symptoms, the term Chilaiditi syndrome is used..$^{1-3}$ Chilaiditi syndrome is a great mimicker since patients may present with signs and symptoms that imitate various medical and surgical emergencies. Initial chest X-ray showed our patient's lungs critically compressed by the distended loops of bowel

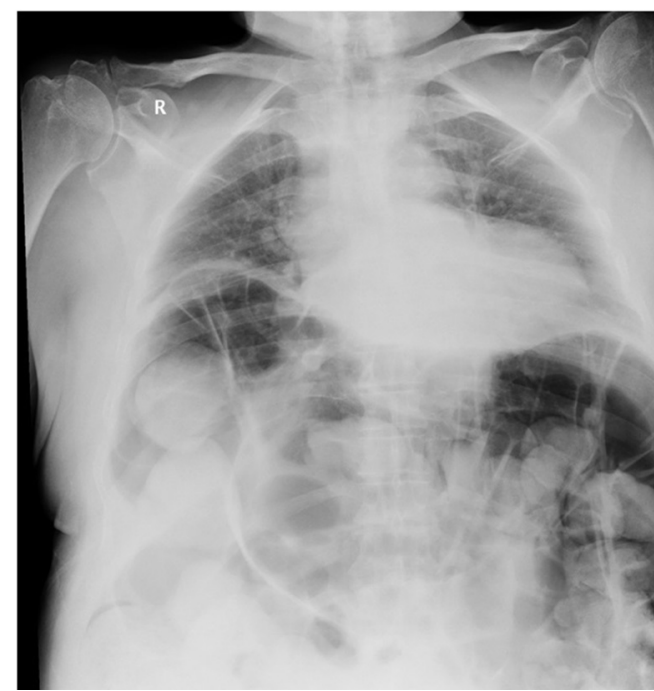

Figure 1 Chest X-ray on presentation showing Chilaiditi sign and lungs compressed.

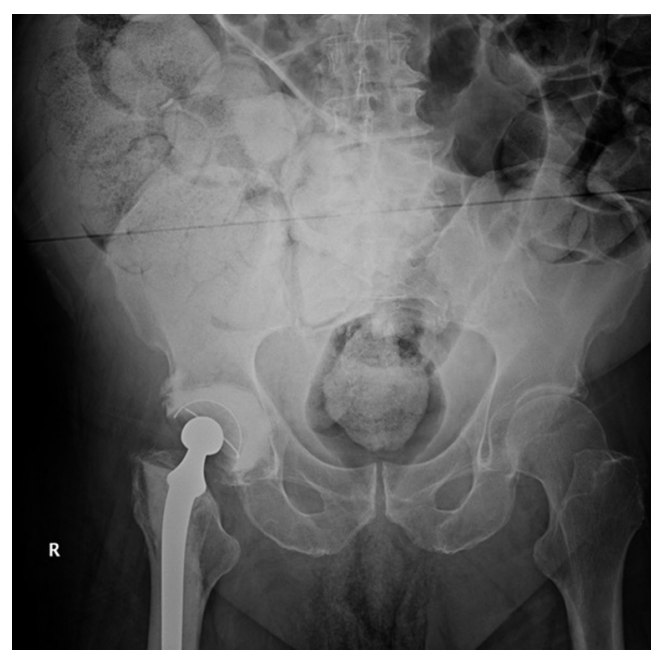

Figure 2 Abdominal X-ray on presentation showing faecal impaction.

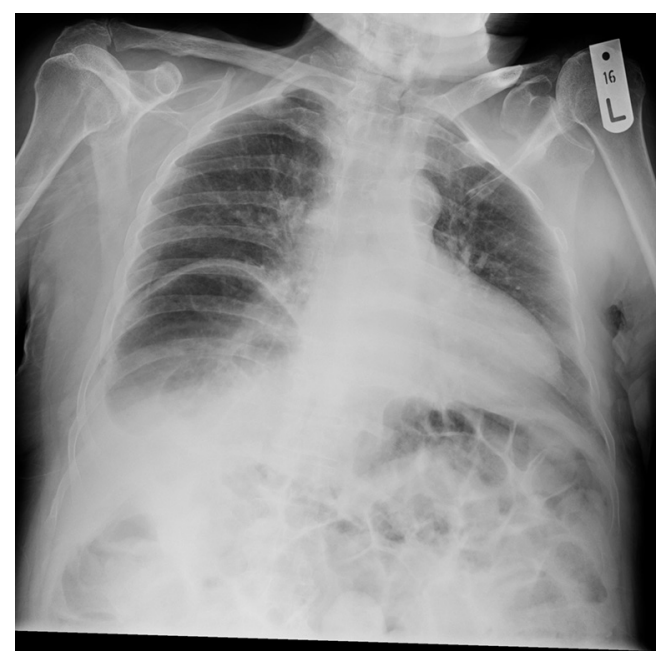

Figure 3 Chest X-ray showing improvement after manual evacuation.

underneath his diaphragms and this was conceivably the cause of his respiratory distress, similar to dyspnoea associated with ascites.

Initial management includes laxatives but surgical intervention may be indicated if bowel obstruction or perforation ensues. ${ }^{12}$

Acknowledgements The author would like to thank Dr. Paula Hickey (Consultant Geriatrician, Sligo University Hospital, Sligo, Ireland), who oversaw the care of the patient from admission till discharged.

Contributors J00: admitting doctor, conception, acquisition of data, write-up of the case, referencing.

Competing interests None declared. 


\section{Learning points}

- In patients with respiratory distress and incidental Chilaiditi sign, it is important to consider Chilaiditi syndrome as a cause for sudden deterioration as prompt bowel decompression would be paramount.

- Though rare, Chilaiditi syndrome may be associated with severe complications if diagnosis is overlooked.

Patient consent Obtained from next of kin.
Provenance and peer review Not commissioned; externally peer reviewed.

(C) BMJ Publishing Group Ltd (unless otherwise stated in the text of the article) 2017. All rights reserved. No commercial use is permitted unless otherwise expressly granted.

\section{REFERENCES}

1 Kang D, Pan AS, Lopez MA, et al. Acute abdominal pain secondary to chilaiditi syndrome. Case Rep Surg 2013;2013:1-3.

2 Moaven O, Hodin RA. Chilaiditi syndrome. Gastroenterol Hepatol 2012:8:276-8.

3 Nair N, Takieddine Z, Tariq H. Colonic Interposition between the Liver and Diaphragm: "The Chilaiditi Sign". Can J Gastroenterol Hepatol 2016;2016:1-2.

Copyright 2017 BMJ Publishing Group. All rights reserved. For permission to reuse any of this content visit

http://group.bmj.com/group/rights-licensing/permissions.

BMJ Case Report Fellows may re-use this article for personal use and teaching without any further permission.

Become a Fellow of BMJ Case Reports today and you can:

- Submit as many cases as you like

- Enjoy fast sympathetic peer review and rapid publication of accepted articles

- Access all the published articles

- Re-use any of the published material for personal use and teaching without further permission

For information on Institutional Fellowships contact consortiasales@bmjgroup.com

Visit casereports.bmj.com for more articles like this and to become a Fellow 